\title{
THE TRADITION OF ZAKHIRIDDIN BABUR IN THE SECOND HALF OF THE TWENTIETH CENTURY IN UZBEK POETRY
}

\author{
Shahnoza Muhitdinovna Rakhmonova \\ Teacher, Alisher Nava'i Tashkent state university of the Uzbek language and literature, Tashkent, \\ Uzbekistan.
}

Article DOI: https://doi.org/10.36713/epra4097

\begin{abstract}
In this article, it is analyzed that some well-known people such as Zokhirjon Kholmuhammad's son Khabibiy, Sobir Abdulla, Nabikho'ja Nurillakho“ja’s son Chustiy, Asqarali Charkhiy, ErkinVahidov, Abdulla Aripov, Jamol Kamol continued Babur's tradition in selected literature. They brought the mixture of essence and measure for their poetry work which was used in Bobur's poet last time. Besides, there are analyzed some other works which were connected ghazals (poetic genre) of Bobur.
\end{abstract}

KEYWORDS: Selected poem; takhmis; the weight of Aruz; the weight of KHazaj; measure.

\section{INTRODUCTION}

First of all, the great representative, the founder of dynasty Babur's, king and poet Zakhiriddin Bobur has a strong position in Uzbek literature. He had their role as a specialist in history, literature, and poet. In the second half of the twentieth century was the special phase in the history of Uzbek literature with its essence's summary compositional construction, artistic and illustrative way. In that phase, there were other poets also such as Zokhirjon Kholmuhammad's son Khabibiy, Sobir Abdulla, Nabikho'ja Nurillakho'ja's son Chustiy, Asgarali Charhiy, ErkinVahidov, Abdulla Aripov, Jamol Kamol who skilled in writing poetry. The several poets continued Alisher Navoi and Zakhiriddin Babur's works. They brought to their poem some mixtures of essences and weight from Navoi and Babur's ghazals.

\section{MATERIALS AND METHODS}

In some sources about Turkish Aruz like "Funun ul-balogha", "Mezon ul-avzon", "Treatise of Aruz" ("Mukhtasar") were analyzed about measure by the some Persian poet's work with Turkish poet's work. According to "Mezon ul-avzon" poem which is written by Alisher Navoi, Khusayn Baykharo had gathered Dehlaviy's work that consisted of 18000 couplets for collection as a book and then clarified work's real measure. Dehlaviy's so many works were complicated measure therefore, people even thought some poets got into trouble for understanding. In terms of Baykharo's mission specialists of Aruz wrote weight over each Dehlaviy's poem. After that to write weight over the poem was become a habit. It is clear that the weight is the important and basic part of poetry ghazal sand it gives to couplet the unique method (repetition) [3, 535]. To investigated the poetic measure of selective authors it was proved that the poets choice weight corresponds to the poem's idea and feature. If deep philosophical observation about life and society, hymen and love, the fate of people, pain of parting, are expressed through the weighty and impressive weight that beloved to people picture and his passionate feelings explain with some captivated voice in some easy ways. Besides, the celebration of faithfulness and loyalty was singing in the playful and frisky couplets.

One of the main factors to mark weight is the lhyric genre $[9,3]$. In the section of selection, the authors consider about which genre is created in which measure. Because each genre has their measure 


\section{SJIF Impact Factor: 6.260| ISI I.F.Value:1.241| Journal DOI: 10.36713/epra2016 \\ ISSN: 2455-7838(Online) \\ EPRA International Journal of Research and Development (IJRD) \\ Volume: 5 | Issue: 3 | March 2020 \\ - Peer Reviewed Journal}

position. Some genre's opportunity is wide, so they may be written a variety measure of Aruz structure. However, some measures are written via genrewhich was marked from last time.

\section{RESULT AND DISCUSSION}

Body, Zakhiriddin Babur enrich Uzbek Aruz's weight by the his "Aruz" brochure. One of such kind a lovely weight is hajazi musammani ashtar (weight and taq'te): foilun mafoiylun foilun mafoiylun $-\mathrm{V}-/ \mathrm{V}--$ $-/-\mathrm{V}-/ \mathrm{V}---$. This weight belonging to hazaj bakhri is equal to foilun $(-\mathrm{V}-)$ in the branch of ashtar at the first and second quite weight of mafoiylun also equal to $\operatorname{solim}\left(\mathrm{V}--_{-}\right)$in the second and fourth weight. Alisher Navoi didn't give any information about this measure in his book "Mezonul avzon".

The first information about hazaji musammani ashtar is given at the "Treatise of Aruz" ("Mukhtasar") which is written by the Babur. He acknowledged one thing in his works that he informed us "Mustam'ali matbu". He counted this weight in the range of lovely

\begin{tabular}{|l|l|l|l|l|l|l|l|l|l|l|l|l|l|}
\hline Xush & tu & rur & vi & so & li & yor & an & da & bol & ma & sa & day & yor \\
\hline- & $\mathrm{V}$ & - & $\mathrm{V}$ & - & - & - & - & $\mathrm{V}$ & - & $\mathrm{V}$ & - & - & $\sim$ \\
\hline Bo'l & sa & vas & $\mathrm{l}(\mathrm{i})$ & be & $a g^{\prime}$ & yor & dav & la & tu & sa & o & dam & tut \\
\hline- & $\mathrm{V}$ & - & $\mathrm{V}$ & - & - & - & - & $\mathrm{V}$ & - & $\mathrm{V}$ & - & - & - \\
\hline
\end{tabular}

This measure has not any independent, selective poem which was written by the Zakhiriddin Bobur. However, Sobir Abdulla wrote a satirical poem. It called "Sheykh" and in this way, he continued the tradition. Babur's ghazals played as a basic source for other poet's works. For example, Khabibiy, Sabir Abdulla, Charkhiy, Chustiy, Erkin Vakhidov used Babur's ghazal as the main source. Khabibiy's "Etting" repeated ghazals looks price of creating the process of poem.

Ey qaro ko 'zim, ul kun o'zni oshkor etding, $K{ }^{\prime} z$ uchida bir boqding, dil qushini oshkor etding [10, 169].

(Ey black eye on that day you devise yourself You glance me and spoil bird of soul).

In this work, it is obvious that the poet's proficiency at working on the measure. Devise and spoil words come to near with original couplet and this method make poem enchanting in the couplet. There is an example given from Charkhiy's ghazal below.

Sobiro, salomingdanchehrasozerurko 'ngil

Zavqlipoyomingdansarafrozerurko 'ngil [13, 61].

(Sobiro! The soul would be happy from your hello My heart will be happy from your delightful footstep)

In the initial part of the poem of Charkhiy, the repeated section consist of collocation. This method is called "muraddaf" in the history of selected literature. In the case of repeated couplet, the seething mood soaks up the reader's spirit. Another poet Chustiy's measures. In that way, Bobur addressed to Jamiy and Khafiz then set his ghazals in a creative work of example from his own ghazals.

$G$ 'ofil o 'Ima ey soqiy, gul chog'in g'animat tut, Vaqti aysh erur boqiy, ol chog'ir, ketur, bot tut [4, 20]. Foilun - mafoiylun - foilun - mafoiylun

(Ingrate don't dye! Ey whine - server you know the heyday time as a valuable

Time is amusement, so take a wine, in the transition of time).

The given couplet is a philosophical theme and it was known as an only one selective poem written by Zakhiriddin Babur. Usually, according to Aruz rules, the poem's initial parts and couple bytes are written as the main measure. The single bytes are written an additional close to measures. The initial parts of the poem are written at hazaji musammani ashtar. The single byte of the fourth couplet was written hazaji musammani ashtari musabbagh: foilun mafoiylun foilun mafoiylon $(-\mathrm{V}-/ \mathrm{V}---/-\mathrm{V}-/ \mathrm{V}--\sim)$

\section{Charkhiy's.}

independent poem have also the same affair with

She'r bolam quchog 'imga bir jahon bo 'lib kelgil, Saqlagil bu gulbog'ing, bog'bon bo 'lib kelgil [14, 198]. (Poet! Come to my kid's embrace with a huge emotion

Keep these flowers in the garden and come as a gardener).

The poets of ErkinVakhidov created in hazaji musammani ashtar weight are written in theme of precepts at the basis of mudraf rhyme. The poet used both types of rhyme rhymes in these bytes of ghazals and opened up the possibilities of weight.

\section{Doimo dedim, bo 'Ima \\ Oshno, parishonlik, \\ Bo "ldi oshno dilga}

Doimo parishonlik $[6,80]$.

(Always I said, don't be friend to confusion,

If you become friend, you have always confusion). Either:

\section{Kimda iqtidor yo 'qdir, \\ Ilm ila hunar zoe,}

Iqtidor berurman deb,

Chekma ranj, ketar zoe [6, 74].

(The knowledge and craft idle if people have not skill, To give power others Don't embarrass, there will be not any result).

The first citation in the byte o vowel is a stretched of the word "friend-oshino" and "always- 


\section{SJIF Impact Factor: 6.260| ISI I.F.Value:1.241| Journal DOI: 10.36713/epra2016 \\ ISSN: 2455-7838(Online) \\ EPRA International Journal of Research and Development (IJRD) \\ Volume: 5 | Issue: 3 | March 2020 \\ - Peer Reviewed Journal}

doimo" and rhyming words ending with it. The second matte byte uses the next type of rhyme, which consists of one consonant with a short vowel. The words "crafthunar" and "leave- ketar" in the byte are rhyming with each other, and the preceding "a" is a Tawheed - tavjid, forming a rhymed rhyme. Above we have mentioned that Zakhiriddin Babur uses two weights in the Tut radical ghazal. During the analysis, it was found that the ghazals of Habibiy and Charhiy were written in hazaji

musammani ashtar and hazaji musammani ashtari musabbagh weights.

If taken into consideration, this weight also has a small rhythmic pause in the strings. That is, after the two routers (mafoulu and mafa'ilun) there is a small pause within the cornea, which is achieved by the equation of the word and the rhyme, in other words, the separation becomes between the turoq which is coming in the "finger" weight. Here is given this affair based on ErkinVahidov'sghazal.

\begin{tabular}{|l|l|}
\hline Yormi ko'zguga boqqan / & yorga yo boqar ko'zgu, \\
\hline foilun mafoiylun / & foilun mafoiylun \\
\hline Yor yuzini ko'rganda/ & Suv bo'lib oqar ko'zgu [6, 107]. \\
\hline foilun mafoiylun / & foilun mafoiylun \\
\hline
\end{tabular}

In the second half of the twentieth century, there was created ghazal in the hazaji musammani ashtar weight as well as independent (natural) masters. Specifically, in this measure, there are given four independent Mukhammas (consist of 5 couplets) written by Sobir Abdulla. The first paragraph of his "Impartially advise" begins with:

Kalta o 'ylamay she'r yoz, o'ylashib uzun hal qil, Yakka-dukka gap tuzmay, satrini mufassal qil, Bo'lma kambag 'al, tilga boyliging mukammal qil, Ma'nili, shirinlikdan xalqni unga mahtal qil, Umruzoq asarlardan sen o 'zingga haykal qil [2, 129]. (Write a poem without thinking, and think long, Describe the line without saying a single sentence, Don't be poor, and make perfect your vocabulary, Through the meaning, sweetness, make people need it Make sculptures of yourself from the more beautiful works).

It is understood that the above mentioned the given couplet is in the measure of hazaji musammani $\operatorname{ashtar}(-\mathrm{V}-|\mathrm{V}---|-\mathrm{V}-\mid \mathrm{V}---)$ and it written about precepts. The detailed and perfect words in the Mukhammas banch create "tanosub", it means lair of words and the phrase-long, poor and rich words express contrast meanings, so this affair creates "tazod" it means confusion,

In the poetry of the second half of the twentieth century, the type of "taxmis" in the Mukhammas has a special place. It is well known that the taxmis has written is based on a ghazal. Three new lines are added to each byte by a particular ghazal. It is well known in the classical literature that the poets tie Mukhammas to their own ghazals (AlisherNavoi, Ogakhiy) and the ghazals of other authors.

According to D.Yusupova's article "The taxmis (Prophets) of Alisher Navoi" all 10 poems by AlisherNavoi included in "Khazoyinul-maoni" are taxmis, that the Mukhammas is appeared by the use ghazal five times; It is noted that 3 of the poets are attributed to "malikul-kalom" who is Lutfi, and the other 7 are based on the poet's own ghazals $[15,143]$.

Traditionally, the poetry of the second half of the twentieth century has preserved the weight and rhyme of the ghazal, which is closely connected. The genre of Mukhammas (approx. Sh.R.) has strict requirements: the three lines of ghost byte of the predecessors must be so harmonious in terms of content, weight, and art that every five lines must give the impression that they are like a poet $[7,175]$. The taxmises created in the second half of the 20th century are of particular importance as they fully meet these requirements.

ErkinVokhidov tied a taxmis to Zakhiriddin Bobur's ghazal, that called "When will it be?" This ghazal is a lovable subject and is about 5 bytes. All bytes are displayed by ErkinVahidov. It is noteworthy that linking taxmis to all is not uncommon in our literature. The poet also kept the weight in the tie. The theme of the Ghazal continues with skill.

Yetolmay qomatim yodur necha oykim, hilolingga, Qaro ko'z mardumi yig 'lab tikilmoq birla holingga, Qachon ul totli kun kelgay, yetarman lahza bolingga,

Qachon bo'lg'ay, musharraf bo'lg 'amen, jono, jamolingga,

Qutulg'aymen firoqingdan, yetishgaymen visolingga? [7, 121]

(How many moons I couldn'treach to your face?

Do you want to look at your eyes and birthmark, weeping,

When that great day arrives, you will be ready for a moment,

When it comes to your being, my soul, your glory,

I will ged rid of your parting, and then reach your beauty).

The given taxmis and the underlying ghazal are created in Aruz's system of measures in hazaji 


\section{EPRA International Journal of Research and Development (IJRD)}

musammani solim (mafoiylun mafoiylun mafoiylun mafoiylun) $\mathrm{V}---/ \mathrm{V}---/ \mathrm{V}---/ \mathrm{V}---/ \mathrm{V}---)$. The lines mentioned in the paragraph belong to the Zakhiriddin Babur pen, and the above three verses are written by Erkin Vakhidov. The rule of mudrafrhyme which is used in ghazal has been preserved.

Let's also analyze Jamal Kamal's commentary on Zakhiriddin Babur's ghazal that begins with "like leaf of Hazon ..." Babur's second ghazal, which became the foundation of taxmis was also a lovable subject, and it was created in hazajimusammanisolim weight .Jamal Kamal also retained his weight while linking the Babur ghazal. This assumption begins with the following paragraph:

Ne davronlar o' zim-la mast edim, mastona o' ynardim, Yopishdi qaydanam bu $\operatorname{dog}^{6}$ i so' zon, bu balo dardim,

O’ zingsan barchasiga chin sababkor, nozparvardim,

Hazon yaprog' i yanglig gul yuzing hajrida sarg ardim,

Ko' rib, rahm aylagil, ey lolaruh, bu chehrayi zardim [8, 247].

(I used to be drunk with myself, I danced like mad Where did came from to me this drop of pain?

The main causer is you for all of things,

Like a fall of the leaves leaf, I turned yellow in parting of your flowers face,

See, dome mercy, tulip spirit, this is my poor face).

The lines mentioned here belong to the Babur pen, and the three verses above are written by Jamal Kamal. The basis of the rhyme consists of raviys (the rhymes which correspond to each other) letter. In taxmis raviy consist of such kind of words: I would play (oynardim), my pain (dardim), my capricious (nozparvardim), I am turning yellow (sarg 'ardim), my gold (zardim). " $R$ " consonant mentioned as a raviy and it combined all of the couplets.

\section{CONCLUSION}

In the second half of the twentieth century, ghazals were written in the musammani ashtar weight and Uzbek poetry enriched with such kind a new theme in KHabibiy, Sabir Abdulla, Charkhiy, Chustiy, Erkin Vakhidov. In this kind of weight of ghazal sare dominated by love and discipline. The poets continued the tradition by giving a tribute to the ghazals of Zahiriddin Babur. They also in corporated his elegance in herent in their poetry.

\section{REFERENCES}

1. Abdulla Sabir. Devon. - T.: Fiction, 1965. - B. 313

2. Abdulla Sabir. Selected works. 4 drops. 2 pm. - T .: Publishing House of Literature and Art named after Gafur Ghulam, 1976. - B 333.

3. Alisher Navoi. Criterion ul. MATT. 20 drops. Volume 16 - T.: Science, 2000. - B. 246.

4. Bobur Zakhiriddin. Devon. Prepared by A.Abdugafurov. - T.: Science, 1994. - B. 144.
5. Bobur Zakhiriddin. In short. Publisher S. Hasan. - T .: Science, 1971. - B. 412.

6. Vohidov Erkin. Selected works. - T .. East, 2018. B. 689.

7. Jabborov Nurboy. The time. Criterion. Poetry. - T .: Publishing house of Literature and Art named after Gafur Gulom. - B. 304.

8. Jamal Kamal. Farewell to the century. Elections. The first volume. - T: Science, 2007. - B. 336.

9. Rustamov Aliybeg. Conversations about Aruz. - T .: Science, 1972. - B. 3.

10. KHabibiy. Devon. - $T$.: Publishing House of Literature and Art named after Gafur Ghulam, 1975. - B. 536.

11. Hojiahmedov Anvar. Uzbek Aruzi dictionary. - T.: East, 1998. - B. 224.

12. Hojiahmedov Anvar. Furkat 's of aruz / Creativity Furqat. - T.: Science, 1990. - B. 83.

13. Charkhiy. Crossed: Poems. - T .: Academy, 2010. B. 220.

14. Chusty. Biography. - $T$.: Publishing House of Literature and Art named after Gafur Gulom, 1988. - P. 480.

15. Yusupova Dilnavoz. The taxmis (Prophets) of Alisher Navoi // Star of the East. - Tashkent, 2013. №2. - 143-147. 